\title{
Effect of Salicylic Acid on Growth and Physiological Status of Salt Stressed Sour Orange Seedlings (Citrus aurantium L.)
}

\author{
Samy M. El-Shazly ${ }^{1}$, Hoda A. Khali1 ${ }^{1}$, Shaimaa F. Abd El-Hamed ${ }^{1}$ \\ ${ }^{1}$ Department of Pomology, Faculty of Agriculture, Alexandria University, Aflaton street, \\ 21545-El Shatby, Alexandria, Egypt. \\ * Email address: hodaagri@ hotmail.com, hoda.khalil@alexu.edu.eg
}

\section{ABSTRACT}

A Pot experiment was conducted to determine the effect of exogenous salicylic acid (SA) application on growth, chlorophyll content, catalase (CAT) activity, peroxidase (POX) activity, cell membrane ionic permeability (electrolyte leakage), leaf and root $\mathrm{K}^{+} / \mathrm{Na}^{+}$ratio of sour orange seedlings grown under salt stress and greenhouse conditions. Sour orange seedlings were treated with SA at two concentrations $(0.15 \mathrm{mM}$ as a foliar spray and $0.25 \mathrm{mM}$ as a soil application). Two treatments in both seasons were pre-treated with $0.15 \mathrm{mM}$ or $0.25 \mathrm{mM}$ of SA for one month before application of salinity treatment (acclimation treatment). Salinity treatments were established by irrigating seedlings twice a week with saline solution contained 0,75 , and $100 \mathrm{mM}$ of $\mathrm{NaCl}$. Salt stress negatively affected plant growth and chlorophyll content of sour orange seedlings. However, seedlings treated with SA often had greater plant length, leaf area and total dry weight as well as higher chlorophyll content under salt stress. Leaf peroxidase enzyme activity (POX) was reduced in response to salt stress while electrolyte leakage was raised. SA treatments induced increases in CAT and POX activity and decreases in electrolyte leakage compared to the control under salt stress. With respect to the nutrient content, SA treatment as a foliar spray $(0.15 \mathrm{mM})$ increased the leaf and root $\mathrm{K}^{+} / \mathrm{Na}^{+}$ratio as compared with control. The greatest values for most measurements were often obtained by the $0.15 \mathrm{mM} \mathrm{SA}$ as a foliar spray. The treatment with SA one month before salt treatment (acclimation) did not exhibit a pronounced effect in comparison with SA without acclimation. These findings suggest that the SA treatments can ameliorate the negative effect of salinity on the growth of sour orange seedlings.

Key words: salinity, salicylic acid application, catalase, peroxidase, electrolyte leakage.

\section{INTRODUCTION}

Salinity is one of the major environmental abiotic stresses which is considered the most serious limiting factors for crops growth and production in many regions in the world especially in arid and semi-arid regions. Total area under salinity is about 953 million hectares which represents about $8 \%$ of the land surface (Singh, 2009). The saline substrates have adverse effects on plants including primary injury; which includes the toxic effect of ions and secondary injury; which includes nutrition deficiency and osmotic effect; according to the classification of Bernstein (1964).

The citrus is classified as sensitive plants to the salinity (Maas, 1993 and Khalil et al. 2011), Increasing salinity in irrigation water reduces citrus trees growth and fruit yield (Garcia-Sanchez et al., 2006 and Prior et al., 2007). Salt stress is known to perturb a multitude of physiological processes in plants (Noreen and Ashraf 2008). Salt stress causes oxidative stress on plants by inducing them to generate reactive oxygen species (ROS) such as superoxide $\left(\mathrm{O}_{2}^{-}\right)$, hydrogen peroxide $\left(\mathrm{H}_{2} \mathrm{O}_{2}\right)$, hydroxyl radical $(\mathrm{OH})$, and single oxygen $\left({ }^{1} \mathrm{O}_{2}\right)$, which can damage mitochondria and chloroplasts by disrupting cellular structures (Mittler,2002). Therefore, photosynthesis will be reduced because the photosynthetic capacity depends on amount of photosynthesizing tissue (leaf area), photosynthetic pigments and movement of stomatal behavior and inhibition of photo-chemical processes (Dubey 2005). The decrease in photosynthesis may lead to reduction in growth and yield. To scavenge ROS, synthesize of different types of antioxidant compounds or activating key antioxidant enzymes can be used (Mittler, 2002). So, numerous investigators suggested that salt tolerance could be induced by enhancing antioxidant capacity of plants by using antioxidant compound such as salicylic acid (Aberg 1981) and (Noreen and Ashraf, 2008),

Salicylic acid is one of the groups of common phenolic compounds that are produced naturally by plants, which can act as endogenous plant growth regulator (Aberg, 1981). The chemical structure of SA is composed of an aromatic ring bearing a hydroxyl group and it deduced as 2-hydroxy benzoic acid (Delaney, 2004). In addition, SA could be classified as phytohormones. Plant growth regulators play an important role in regulating the growth under stressful environmental conditions, among these growth regulators is SA. Salicylic acid (or ortho-hydroxy benzoic acid) plays an important role in regulating a number of physiological processes in plants (EL-Tayeb 2005 , 
Yusuf et al., 2008 and Hayat et al., 2010), including seed germination (EL-Tayeb 2005), growth (EL-Tayeb 2005 and Yusuf et al., 2008), ion uptake and transmission (Sakhabutdinova et al.,2003), photosynthesis (Noreen and Ashraf 2008), stomatal closure (Gunes et al.,2005) membrane permability (EL-Tayeb, 2005), and storage life (Zhang et al.,2003). The SA plays a key role in development, plant growth and defense responses under biotic and a biotic stress conditions, so SA is considered to be a plant signaling molecule (Cameron, 2000). The signal molecule plays role through participation in some signal transduction systems. SA activates the expression of several defense-related genes (Loake and Grant, 2007). SA induces synthesis of some enzymes that participate in proline biosynthesis or causes accumulation of compatible solutes such as, proline and glycinebetaine, which play a role as defense compounds under stress conditions (Misra and Saxena, 2009). SA has been shown to inhibit ethylene biosynthesis and action (Zhang et al., 2003). SA is also used as a febrifuge and painreliever for human in more gentle low acidity or of acetylsalicylic acid or aspirin.

Hence, improving the performance of fruit trees grown under saline conditions water by introducing newly non-expensive procedures and techniques are the real challenge for scientific research. The use of salicylic acid (SA) under high $\mathrm{Na}$ and $\mathrm{Cl}$ levels was proposed by numerous investigators to improve crop responses and water economy of field crops (Hela et al., 2009; Karlidage et al., 2009 ; Najafian et al., 2009).

Therefore, the objective of this investigation was to study the effect of salicylic acid (SA) in alleviating the damaging effects of salinity stress environmental conditions on sour orange rootstocks seedlings.

\section{MATERIAL AND METHODS}

The present investigation was conducted during the two growing seasons of 2010 and 2011, in order to study the effect of salicylic acid on growth, physiological and nutritional status of salt stressed sour orange seedlings (Citrus aurantium, L.). One-year and six months - old sour orange (Citrus aurantium, L.) seedlings were used in this study. The seedlings were individually planted in black polyethylene bags, $34 \mathrm{~cm}$ in height and 29 $\mathrm{cm}$ in diameter, full with about $4 \mathrm{~kg}$ of sand and clay soils mixed at the ratio of $2: 1$, the seedlings were held in the greenhouse of the Agricultural Experimental Station of the Faculty of Agriculture, Alexandria University. Before the commencement of the different treatments, the seedlings were irrigated twice a week with tap water. For pest protection the seedlings were sprayed with $2.5 \mathrm{~cm} / 1$ Vertimec twice during the summer. During the second season, Super Grow fertilizer was added to each plant as soil application at the rate of $10 \mathrm{~g} / 20 \mathrm{l}$ of irrigation water. Each liter from The Super Grow fertilizer contained $20 \% \mathrm{~N}, 20 \% \mathrm{P}_{2} \mathrm{O}_{5}$ $20 \% \mathrm{~K}_{2} \mathrm{O}, \quad 0.03 \% \mathrm{Fe}, \quad 0.05 \% \mathrm{Zn}, \quad 0.03 \% \mathrm{Mn}$ $0.02 \% \mathrm{Mg}, 0.01 \% \mathrm{Cu}, 0.001 \% \mathrm{~B}$, and $0.0001 \% \mathrm{Mo}$

During the period of adaptation, all seedlings seemed healthy, vigorous and well established. Ninety-six sour orange seedlings, uniform as much as possible, were selected for this study. The experimental seedlings were arranged in Randomized Complete Block Design (RCBD), with twelve replicates for each treatment. Thus, 96 seedlings ( 8 treatments $\times 12$ replicates) were used in each experimental season. The commencement of salt treatments began on the $12^{\text {th }}$ of July and $15^{\text {th }}$ of June 2010 and 2011, respectively. The experimental treatments were conducted by irrigating each plant, twice a week; with $500 \mathrm{ml}$ of the experimental salt solution alone or in combination with salicylic acid. The salt solution was made of sodium chloride $(\mathrm{NaCl})$ added at a concentration of $75 \mathrm{mM}$ in the first season and $100 \mathrm{mM}$ in the second season. The highly concentration $(100 \mathrm{mM})$ of sodium chloride in the second season was used to test the ability of SA to alleviate supreme degrees of salinity stress under the same circumstances. The seedlings of contro and SA foliar or soil applied were irrigated with tap water. Salicylic acid treatments were a foliar sprayed at $0.15 \mathrm{mM}$ and soil application at $0.25 \mathrm{mM}$. (The concentration of SA application on the leaves was lower than on the soil to avoid leaves damages). SA was added either alone, directly combined with the salt solution, or one month before salt application (foliar and soi acclimation). The selected seedlings were subjected to the following treatments:-

1-Tap water (Control)

$2-\mathrm{NaCl}$

3-SA foliar application

4-SA soil application

5-SA foliar $+\mathrm{NaCl}$

6- $\mathrm{SA}$ soil $+\mathrm{NaCl}$

7-SA folir acclimation then $\mathrm{NaCl}$

8-SA soil acclimation then $\mathrm{NaCl}$

The experiment was terminated after 116 days and 128 days, in 2010 and 2011 seasons, respectively. The treatments were terminated when salt treated seedlings in the salt treatments without salicylic acid showed leaf color changes and frequent leaf burns and abscission.

\section{Plant growth and leaf area}

The total growth of the experimental seedlings was estimated by measuring the length of each plant at the termination of each experimental season. The total growth of the experimental seedlings was estimated by measuring the length of each plant at the termination of each experimental season. At the end of either experimental season, 
all leaves of each plant were collected and the leaf area was estimated using three drawn leaves randomly selected from each plant at the end of both experimental seasons, according to the method of Radwan (1973)

\section{Leaf total chlorophyll content}

Total chlorophyll was determined in a fresh leaf sample composed of 3 leaves using a Minolta SPAD chlorophyll meter. According to the method described by Yadava (1986). The results were expressed as SPAD units.

.3. Leaf catalase (CAT) and peroxidase (POX) activity

For the determination of leaf catalase (CAT) and peroxidase (POX) activity, a fresh leaf sample composed of 5 leaves was takes from each experimental plant on the first and $16^{\text {th }}$ of November 2010 and October 2011, respectively. The leaf peroxidase activity was assayed as described by Nir et al., (1986) and expressed as changes in the optical density (O.D) at $470 \mathrm{~nm}$ for 6 -120 seconds after the substrate was added. The leaf catalase activity was assayed as described by Kar and Mishra (1976) analyzed according to $\mathrm{KMnO} 4$ titration method and expressed as $\mu$ mole $\mathrm{H}_{2} \mathrm{O}_{2}$ reduced g ${ }^{-1} \mathrm{FW}$ min $^{-1}\left(\mu\right.$ mole $\mathrm{H}_{2} \mathrm{O}_{2} / \mathrm{g} \mathrm{FW} /$ $\min$ ).

4. Cell membrane ionic permeability (electrolyte leakage)

At the end of both seasons, 3 leaves/ plant were taken at random, and their membrane permeability (electrolyte leakage) was determined as described by Dionisio-Sese and Tobita (1998). Leaf discs from fresh seedlings were cut into $2 \mathrm{~mm}$ pieces and placed in test tubes containing $10 \mathrm{ml}$ distilled water. The tubes were incubated in water bath at $32^{\circ} \mathrm{C}$ for $2 \mathrm{hr}$ and the initial electrical conductivity of the medium $\left(\mathrm{EC}_{1}\right)$ was measured. The samples were autoclaved at $121^{\circ} \mathrm{C}$ for $20 \mathrm{~min}$ to release all electrolyte leakage; cooled to $25^{\circ} \mathrm{C}$ and the final electrical conductivity $\left(\mathrm{EC}_{2}\right)$ was measured with Conductimeter GLP 31 CRISON, made in EEC. The electrolyte leakage (EL) was calculated from the following equation:

$\mathrm{EL}=\mathrm{EC}_{1} / \mathrm{EC}_{2} \times 100$.

\section{Total dry weight}

At the end of both experimental seasons, the seedlings were carefully lifted from the polyethylene bags. The leaves, stems and roots of each experimental plant were separated, washed several times with tap water, rinsed three times in distilled water and then oven dried at $70^{\circ} \mathrm{C}$, to a constant weight. The dry weight of leaves, stems and roots of each plant were recorded.

\section{Leaf and root $\mathrm{K}^{+} / \mathrm{Na}^{+}$ratio}

For leaf and root $\mathrm{K}^{+} / \mathrm{Na}^{+}$ratio determination, $0.3 \mathrm{~g}$ of the leaf and root ground materials of each replicate was digested by sulfuric acid and hydrogen peroxide, according to Evenhuis and De- waard (1980). In this digested solution, potassium and sodium were determined by a flame photometer and $\mathrm{K}^{+} / \mathrm{Na}^{+}$ratio was calculated.

\section{Statistical analysis}

The data obtained throughout the course of this study were statistically analyzed according to the analysis of variance as described by Snedecor and Cochron (1980) using the statistical MSTAT-C package (1996). Comparisons between means were made by $F$-test and the least significant differences (LSD) at level $P=0.05$.

\section{RESULTS}

\section{Plant length and leaf area}

Data in Table (1) indicated that the length an leaf area of sour orange seedlings were greatly influenced by both salinity and SA treatments. A gradual decline in the length of the seedlings and their leaf area was observed with increasing the salinity concentration of the irrigation water. The decline was statistically significant at 75 or 100 $\mathrm{mM}$ as a compared with control during first and second seasons, respectively. SA application improved the length of sour orange seedlings, as compared with those irrigated only with tap water, without any SA. This result was significant in both experimental seasons. The results of the present investigation also indicated that all seedlings grown under salinity conditions and receiving SA application showed higher length than those grown under control and salinity without SA addition. Regarding the influence of SA addition (folia spray or soil application) on the leaf area of sou orange seedlings, the data in Table (1) revealed that in both seasons, seedlings treated with SA alone as foliar or soil application had significantly highe leaf area than control seedlings or those subjected to salinity. Moreover, seedlings treated with SA and subjected to salinity had higher leaf area than those treated with salinity only. In addition, seedlings treated with SA one month before being subjected to salinity recorded higher leaf area as compared to those treated with SA and salinity (without acclimation).

\section{Total dry weight}

Concerning the effect of salinity stres conditions, data of this investigation, generally indicated that salinity exerted an apparent negative influence on the total dry weight of the experimental seedlings (Table 1). For example, in 2010 season, seedlings irrigated of $75 \mathrm{mM}$ salinity level showed a reduction as much as $49.60 \%$, in comparison with those grown under control condition. The corresponding value for 201 season was $64.90 \%$. Data shown in Table (1) also indicated significant higher total dry weights with seedlings receiving $0.15 \mathrm{mM}$ and $0.25 \mathrm{mM}$ SA in the first season and $0.15 \mathrm{mM}$ SA only in the second season, as compared with those irrigated only with tap water. 
Table 1: Effect of salinity stress and salicylic acid (SA) on plant length, leaf area, and total dry weight of sour orange plants during 2010 and 2011growing seasons

\begin{tabular}{lcccccc}
\hline Treatments & $\begin{array}{c}\text { Plant length } \\
(\mathbf{c m})\end{array}$ & \multicolumn{2}{c}{$\begin{array}{c}\text { Leaf area } \\
(\mathbf{c m} 2 / \text { /eaf })\end{array}$} & \multicolumn{2}{c}{$\begin{array}{c}\text { Total dry weight } \\
\text { (g / plant })\end{array}$} \\
\cline { 2 - 7 } & $\mathbf{2 0 1 0}$ & $\mathbf{2 0 1 1}$ & $\mathbf{2 0 1 0}$ & $\mathbf{2 0 1 1}$ & $\mathbf{2 0 1 0}$ & $\mathbf{2 0 1 1}$ \\
\hline Control & $73.00 \mathrm{c}$ & $67.00 \mathrm{c}$ & $24.23 \mathrm{~d}$ & $30.15 \mathrm{~d}$ & $29.28 \mathrm{~d}$ & $30.81 \mathrm{~b}$ \\
\hline $\mathrm{NaCl}$ & $53.33 \mathrm{f}$ & $42.83 \mathrm{f}$ & $10.93 \mathrm{e}$ & $12.89 \mathrm{~g}$ & $14.75 \mathrm{~h}$ & $10.81 \mathrm{~g}$ \\
\hline SA foliar & $76.58 \mathrm{a}$ & $70.50 \mathrm{a}$ & $30.36 \mathrm{a}$ & $44.32 \mathrm{a}$ & $35.68 \mathrm{a}$ & $34.81 \mathrm{a}$ \\
\hline SA Soil & $75.95 \mathrm{a}$ & $68.75 \mathrm{~b}$ & $27.68 \mathrm{~b}$ & $42.67 \mathrm{~b}$ & $32.96 \mathrm{~b}$ & $30.28 \mathrm{bc}$ \\
\hline SA foliar $+\mathrm{NaCl}$ & $65.33 \mathrm{~d}$ & $64.16 \mathrm{~d}$ & $25.75 \mathrm{c}$ & $27.81 \mathrm{e}$ & $26.33 \mathrm{e}$ & $25.33 \mathrm{e}$ \\
\hline SA Soil $+\mathrm{NaCl}$ & $58.95 \mathrm{e}$ & $56.50 \mathrm{e}$ & $24.11 \mathrm{~d}$ & $26.18 \mathrm{f}$ & $22.90 \mathrm{~g}$ & $23.20 \mathrm{f}$ \\
\hline SA foliar acclimation $+\mathrm{NaCl}$ & $75.00 \mathrm{~b}$ & $56.16 \mathrm{~d}$ & $27.77 \mathrm{~b}$ & $34.29 \mathrm{c}$ & $31.55 \mathrm{c}$ & $29.68 \mathrm{c}$ \\
\hline SA soil acclimation $+\mathrm{NaCl}$ & $73.00 \mathrm{c}$ & $67.00 \mathrm{c}$ & $24.23 \mathrm{~d}$ & $30.15 \mathrm{~d}$ & $29.28 \mathrm{~d}$ & $30.81 \mathrm{~b}$ \\
\hline
\end{tabular}

Means within each column followed by the same letter are not significantly different at level $\mathrm{P} \leq 0.05$.

This increment reached as much as $17.9 \%$ with $0.15 \mathrm{mM}$ SA application and $11.7 \%$ with $0.25 \mathrm{mM}$ SA application in 2010 season and $11.48 \%$ in 0.15 $\mathrm{mM}$ SA in 2011 season. Regarding the interaction effect between salinity and SA application, all seedlings grown under salinity conditions and receiving SA applications had higher total dry weight than those grown under the same salinity level without SA. In general pre-treatment of SA as a foliar spray had higher total dry weight than all treatments under the same salinity level in both experimental seasons.

\section{Leaf total chlorophyll content}

The results of analysis of both experimental seasons indicated that leaf total chlorophyll content significantly decreased with the salinity strength of the media (Table 2). A reduction of as much as $21.19 \%$ and $58.97 \%$ was noticed in the leaf total chlorophyll content of seedlings irrigated with 75 $\mathrm{mM}$ and $100 \mathrm{mM} \mathrm{NaCl}$, as compared with those irrigated only with tap water. The data indicated that a significant increase in leaf chlorophyll was noticed with seedlings receiving as low as 0.15 $\mathrm{mM}$ and $0.25 \mathrm{mM} \mathrm{SA}$ as compared with those not supplemented with SA application. This was valid in 2010, 2011 seasons. In the meantime, the combined effect of salinity and SA, showed that the addition of SA to $75 \mathrm{mM}$ or $100 \mathrm{mM}$ salinity level significantly increased the content of leaf chlorophyll as compared with those grown under $75 \mathrm{mM}$ or $100 \mathrm{mM} \mathrm{NaCl}$ salinity without SA. Pretreatment of SA as a foliar spray significantly increased the leaf chlorophyll content as compared with pre-treatment of SA as a soil application.

\section{Leaf catalase activity (CAT)}

The effects of salinity stress conditions and salicylic acid (SA) application on leaf catalase CAT activity in sour orange seedlings are shown in Figure (1). The results of 2010 and 2011 seasons indicated that the leaf CAT activity decreased with the addition of $\mathrm{NaCl}$ to the media. This decrease was statistically significant in 2010 and 2011 season compared with control. This reduction reached as much as $43.52 \%$ and $58.57 \%$ in 2010 and 2011 seasons in the leaf tissue of seedlings irrigated with $75 \mathrm{mM} \mathrm{NaCl}$ and $100 \mathrm{mMNaCl}$ respectively as compared with those irrigated only with tap water. Application of $0.15 \mathrm{mM}$ SA as a foliar spray caused a significant increase in leaf CAT activity as compared with control seedlings, but this increment was not significant in seedlings receiving as low as $0.25 \mathrm{mM} \mathrm{SA}$ as a soil application in comparison with control seedlings. This effect was clear in 2010 and 2011 seasons. Regarding the interaction effect between salinity and SA, the data showed that the application of SA plus salinity treatment had a positive effect on leaf CAT activity. In 2011 season, pre-treatment with SA $(0.15 \mathrm{Mm})$ gave best results compared to application with $\mathrm{SA}$ and $\mathrm{NaCl}$ without acclimation. No significant differences were obtained between SA at $0.25 \mathrm{mM}$ as a soil application along with salinity or pre-treatment application. Moreover, in 2010 season there was not any significant differences between the application of SA as pretreatment either foliar or soil application and treatments with salinity.

\section{Leaf peroxidase activity (POX)}

Data representing the influence of salinity stress conditions and salicylic acid (SA) on peroxidase (POX) activity in sour orange seedlings are shown in Figure (2). The results of analysis of variance of both experimental seasons indicated that addition the salinity treatment of the media significantly increased the leaf POX activity. This increase was statistically significant under $75 \mathrm{mM}$ and $100 \mathrm{mM}$ salinity levels. In 2010 season, seedlings irrigated with $75 \mathrm{mM}$ of salinity level showed an increment as $45.72 \%$, in comparison with those grown under control conditions. The corresponding value for 2011 season was $58.76 \%$. Application of as $0.15 \mathrm{mM}$ and $0.25 \mathrm{Mm} \mathrm{SA}$ caused a substantial increase in leaf POX activity. This increment was higher in seedlings treated with $\mathrm{SA}$ at $0.15 \mathrm{mM}$ than those treated with $\mathrm{SA}$ at $0.25 \mathrm{mM}$. 
Table 2: Effect of salinity stress and salicylic acid (SA) on leaf chlorophyll, leaf and root $\mathrm{K}^{+} / \mathrm{Na}^{+}$ratio of sour orange plants during 2010 and 2011 growing seasons

\begin{tabular}{lcccccc}
\hline & \multicolumn{2}{c}{$\begin{array}{c}\text { Teaf chlorophyll } \\
\text { content (SPAD) }\end{array}$} & \multicolumn{2}{c}{$\begin{array}{c}\text { leaf } \mathbf{K}^{+} / \mathbf{N a}^{+} \\
\text {ratio }\end{array}$} & \multicolumn{2}{c}{$\begin{array}{c}\text { Root }^{+} / \mathbf{N a}^{+} \\
\text {ratio }\end{array}$} \\
\hline Control & $\mathbf{2 0 1 0}$ & $\mathbf{2 0 1 1}$ & $\mathbf{2 0 1 0}$ & $\mathbf{2 0 1 1}$ & $\mathbf{2 0 1 0}$ & $\mathbf{2 0 1 1}$ \\
\hline $\mathrm{NaCl}$ & $53.08 \mathrm{~cd}$ & $47.03 \mathrm{c}$ & $1.69 \mathrm{~b}$ & $1.32 \mathrm{~b}$ & $1.69 \mathrm{~b}$ & $1.32 \mathrm{~b}$ \\
\hline SA foliar & $41.83 \mathrm{e}$ & $19.29 \mathrm{~h}$ & $0.43 \mathrm{e}$ & $0.29 \mathrm{e}$ & $0.43 \mathrm{e}$ & $0.29 \mathrm{e}$ \\
\hline SA Soil & $57.40 \mathrm{a}$ & $51.44 \mathrm{a}$ & $2.31 \mathrm{a}$ & $1.66 \mathrm{a}$ & $2.31 \mathrm{a}$ & $1.66 \mathrm{a}$ \\
\hline SA foliar $+\mathrm{NaCl}$ & $55.63 \mathrm{~b}$ & $50.72 \mathrm{~b}$ & $1.63 \mathrm{~b}$ & $1.14 \mathrm{bc}$ & $1.63 \mathrm{~b}$ & $1.14 \mathrm{bc}$ \\
\hline SA Soil $+\mathrm{NaCl}$ & $53.64 \mathrm{c}$ & $43.61 \mathrm{e}$ & $1.09 \mathrm{c}$ & $1.04 \mathrm{c}$ & $1.09 \mathrm{c}$ & $1.04 \mathrm{c}$ \\
\hline SA foliar acclimation $+\mathrm{NaCl}$ & $52.41 \mathrm{~d}$ & $38.05 \mathrm{~g}$ & $0.76 \mathrm{~d}$ & $0.67 \mathrm{~d}$ & $0.76 \mathrm{~d}$ & $0.67 \mathrm{~d}$ \\
\hline SA soil acclimation $+\mathrm{NaCl}$ & $55.12 \mathrm{~b}$ & $44.89 \mathrm{~d}$ & $1.21 \mathrm{c}$ & $1.22 \mathrm{bc}$ & $1.21 \mathrm{c}$ & $1.22 \mathrm{bc}$ \\
\hline
\end{tabular}

Means within each column followed by the same letter are not significantly different at level $\mathrm{P} \leq 0.05$.

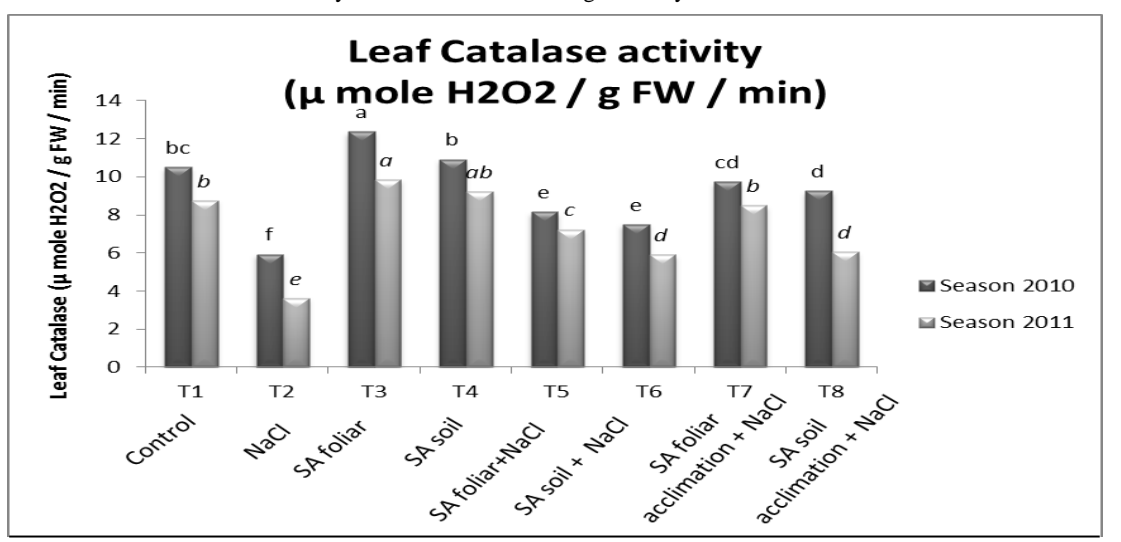

Fig. 1: Effect of salinity stress and salicylic acid on leaf catalase activity of sour orange plants during 2010 and 2011 growing seasons

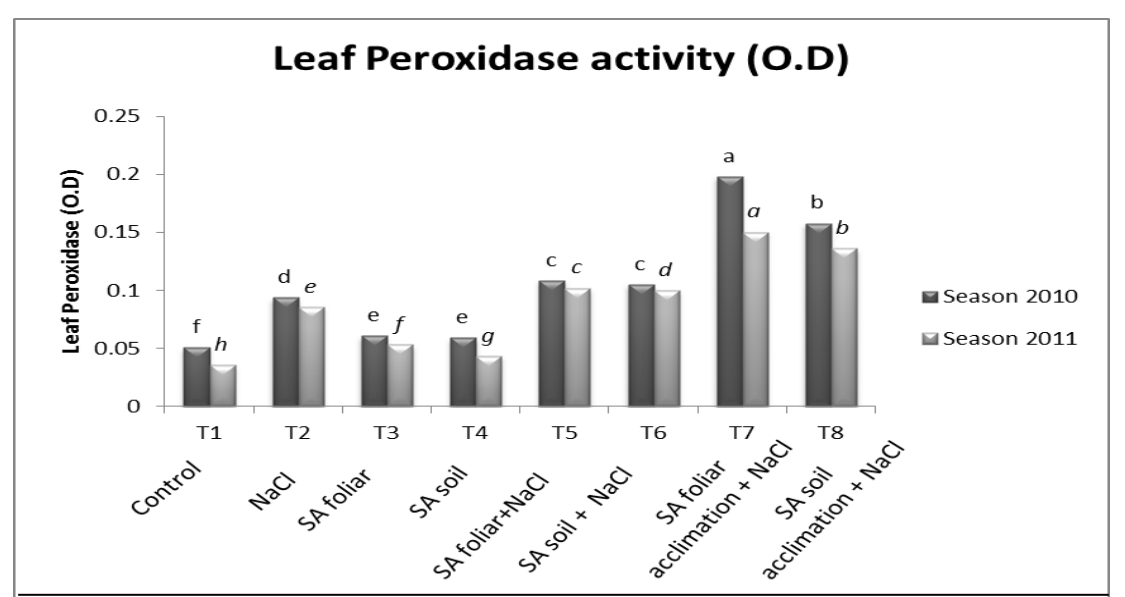

Fig. 2: Effect of salinity stress and salicylic acid on leaf peroxidase activity of sour orange plants during 2010 and 2011 growing seasons 


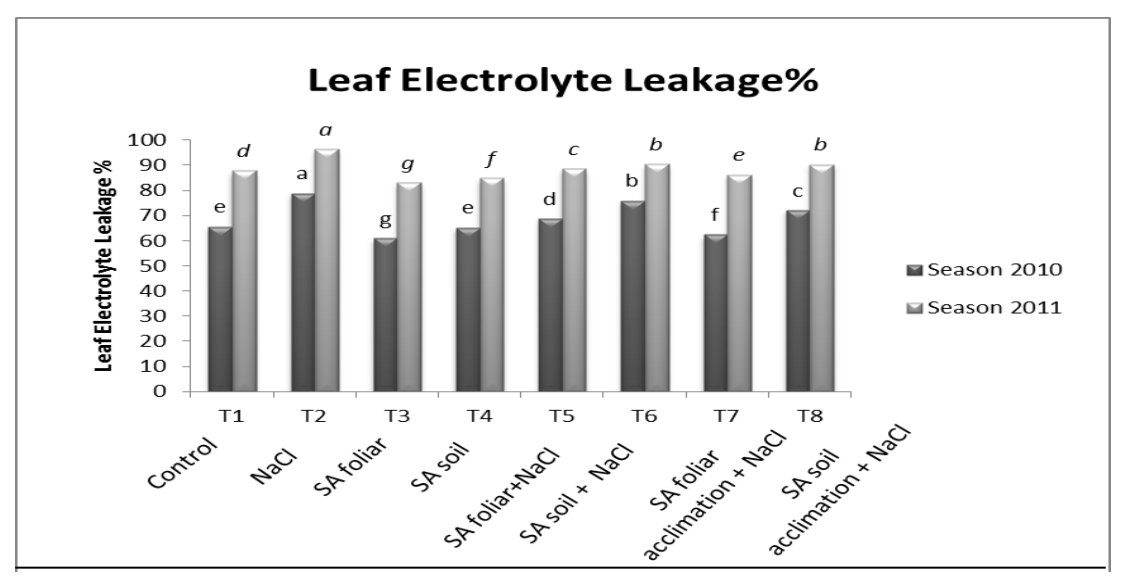

Fig. 3: Effect of salinity stress and salicylic acid on leaf electrolyte leakage\% of sour orange plants during 2010 and 2011 growing seasons

This was valid in 2011 season but in 2010 there were no significant differences between both concentrations. Regarding the combined effect between salinity and SA, data showed that the application of SA along with salinity conditions had a positive effect on peroxidase activity and the application of SA as a foliar spray gave significantly higher peroxidase activity than soil application in 2011 season, but in 2010 there were not significant differences between the foliar and soil applications treatments. The effect of pretreatments of SA on leaf POX activity also was shown in Figure (2). Data showed that pretreatments of SA as a foliar or soil application increased POX activity of leaf tissue under $75 \mathrm{mM}$ and $100 \mathrm{mM}$ salinity stress, the foliar pre-treatment had significantly higher peroxidase activity than soil pre-treatment under the same salinity levels in 2010 and 2011 season.

6. Cell membrane ionic permeability (electrolyte leakage)

The effect of salinity stress condition and SA application on the electrolyte leakage in leaves of sour orange seedlings is shown in Figure (3). The results of both experimental seasons generally indicated that salinity increased the electrolyte leakage in leaf tissues. This increase was statistically significant as compared with those irrigated only with tap water. Salicylic acid application caused a significant decrease in the percentages of electrolyte leakage in seedlings receiving $0.15 \mathrm{mM} \mathrm{SA}$ (a foliar spray application), nevertheless this decrease was not statistically significant with SA at $0.25 \mathrm{mM}$ (as a soil application) as compared with those irrigated only with tap water. This was valid for leaf tissue in
2010. Regarding the interaction effect between salinity and SA, data showed that SA application plus salinity generally decreased electrolyte leakage of leaf tissue at 75 or $100 \mathrm{mM}$ salinity levels.

\section{Leaf and root $\mathrm{K}^{+} / \mathrm{Na}^{+}$ratio}

Data shown in Table (2) indicated that leaf and root $\mathrm{K}^{+} / \mathrm{Na}^{+}$ratio of sour orange seedlings was greatly influenced by both salinity and salicylic acid (SA) application treatments. The results generally indicated that addition of $\mathrm{NaCl}$ to irrigation water led to decrease $\mathrm{K}^{+} / \mathrm{Na}^{+}$ratio in either leaf and root tissues of seedlings. This decline was statistically significant at either $75 \mathrm{mM}$ or $100 \mathrm{mM} \mathrm{NaCl}$ as compared with control during both experimental seasons. Salicylic acid application as a foliar spray $(0.15 \mathrm{mM})$ increased the leaf and root $\mathrm{K}^{+} / \mathrm{Na}^{+}$ratio as compared with those irrigated only with tap water, without any SA, during both experimental seasons. However, there was not any significant difference between $\mathrm{SA}$ at $0.25 \mathrm{mM}$ (as a soil application) and control seedlings. All seedlings grown under salinity stress conditions and receiving SA application showed higher $\mathrm{K}^{+} / \mathrm{Na}^{+}$ratio in leaf and root tissues than those grown under salinity without SA application. Salicylic acid at $0.15 \mathrm{mM}$ significantly increased the leaf $\mathrm{K}^{+} / \mathrm{Na}$ ratio in 2011 and the root $\mathrm{K}^{+} / \mathrm{Na}$ ratio in 2010 more than treatment of $\mathrm{SA}$ at $0.25 \mathrm{mM}$. In general; pre-treatment of $0.15 \mathrm{mM}$ SA combined with salinity was the best treatments on affecting $\mathrm{K}^{+} / \mathrm{Na}^{+}$ratio in leaf and root tissues of sour orange seedlings grown under salt stress conditions. 


\section{DISCUSSIONS}

In this study, there was a gradual decline in the length, leaf area, and total dry weight of the seedlings under salt stress. The fact that salinity adversely affected the length of seedlings was also reported by numerous other investigators such as Khalil et al. (2011); on citrus, Khalil (2013); on grapes, Zou et al. (2013); on trifoliate orange seedlings. They attributed the obvious reduction in length of seedlings under salinity stress conditions to decrease in the water absorbing potential of seedlings under such circumstances. Besides, Hsiao (1973) and Anderson and Brodbeck (1988) pointed out that leaf growth exhibited an increased sensitivity to water deficit, which prevails under salt stress condition, and the first change brought about by water shortage was the slowing down of leaf growth. The decrease in leaf chlorophyll might provide a reasonable explanation for the reduction in total dry weight of salinized seedlings. These results might gain support from those found by numerous other investigators working on various fruit species such as Iglesias et al. (2004) and Wei et al, (2013); on citrus and Sharma et al. (2013); on rough lemon. They reported that there was an appreciable reduction in the total dry weight of the experimental seedlings with increasing the salinity level of the substrate. All salicylic acid treatments were significantly superior over non-treated control for most of the studied parameter. This increase in plant growth, in response to salicylic acid application was also reported by Yill dirim et al. (2008), Hela et al. (2009) and Cornelia et al. (2010). Those authors observed a great increase in the growth (plant length, leaf area and total dry weight) of salicylic acid treated plants when compared with non-treated ones. Shaaban et al. (2011) studied the effect of spraying Anna apple trees by SA at different concentrations and frequencies. They found that there was a gradual increase in leaf area by increasing the concentration of SA from 50 up to $400 \mathrm{ppm}$ and by increasing the number of applications from 1 to 4 sprays. They attributed such effect to the role of SA in activating cell division, biosynthesis of organic foods and availability and movement of mineral nutrients towards the leaves. An interpretation for such foundations was given by Noreen and Ashraf (2008), they suggested that growth enhancement of SA treated plants might be due to the influence of SA in inducing changes in photosynthesis, antioxidant capacity and ion homeostasis processes. Leaf total chlorophyll content of sour orange seedlings significantly decreased with the addition of $\mathrm{NaCl}$ to the media. This reduction could be attributed to the effect of salinity in decreasing absorption of $\mathrm{Fe}$ and $\mathrm{Mg}$ by the plants. (Yehia, 2002). Pre-treatment of SA as a foliar spray increased the leaf chlorophyll content as compared with pre-treatment of SA as a soil application. Similar finding was reported by Purcarea and Cachita-Cosma (2011), they reported that SA pre-treatment as a foliar spray ameliorated the total chlorophyll pigment content of whea seedling leaves under salt stress. Our results showed that leaf CAT activity decreased with the addition of $\mathrm{NaCl}$ to the media, Figure (1). These results confirm those of Helaly and El-Hosieny (2011); working on sweet orange seedling. They reported that CAT activity decreased with increasing the salinity level in irrigation water up to the highest level $(6000 \mathrm{ppm} \mathrm{NaCl})$.Besides, Wu et al. (2010) reported that CAT enzyme is important for plant to tolerate the salinity stress, because CAT dissociates $\mathrm{H}_{2} \mathrm{O}_{2}$ to oxygen and water. Application of $0.15 \mathrm{mM} \mathrm{SA}$ as a foliar spray caused a significant increase in leaf CAT activity as compared with control seedlings. These results are in line with those of Yusuf et al. (2008), Cornelia et al. (2010), and Azooz et al. (2011). They reported that the CAT enzyme activity increased in plants grown under salinity stress conditions and spraying with SA treatment. This could be attribute to the ability of SA to improve the antioxidative capacity of the plants; thereby increasing the plant tolerance to salt stress Addition of the salinity treatment to the media increased leaf peroxidase activity. This increase was statistically significant under 75 mMand 100 $\mathrm{mM}$ salinity levels (Figure 2). These results are in agreement with those reported by El-Tayeb (2005) and Khalil et al. (2009). They all found that increasing salinity level increased leaf peroxidase activity. Salicylic acid is necessary for the induction of antioxidant defenses and maintaining the redox salt of the glutathione pool, it has been shown to be essential for the plant protection against oxidative stress. Plants containing high concentrations of antioxidants show considerable resistance to oxidative damage caused by activated oxygen species (Garratt et al., 2002). Cell membranes are one of the first targets of many plant stresses and it is generally accepted that the maintenance of their integrity and stability unde salt stress conditions is a major component of salt tolerance in plants. The degree of cell membrane injury induced by salinity stress may be easily estimated through measurements of electrolyte leakage from the cells. In the current experiment, salinity increased the electrolyte leakage in lea tissues and this increase was statistically significant as compared with those irrigated only with tap water (Figure 3 ). These results are in agreement with those reported by El-Tayeb (2005) and Karlidage et al. (2009). Experimenting with strawberry plants, Karlidage et al. (2009) studied the effect of salinity stress and SA on electrolyte leakage. They found that $35 \mathrm{mM} \mathrm{NaCl}$ raised leaf 
electrolyte leakage from 15 to $35 \%$. However, exogenous SA treatments lowered the electrolyte leakage of salt stressed plants as compared to salt stressed ones without SA. They pointed out that high $\mathrm{Na}$ caused membrane disorganization and that SA facilitated the maintenance of membrane function by protecting it from oxidative damage. Several studies have reported negative correlations between leaf $\mathrm{K}^{+} / \mathrm{Na}^{+}$ratio and salinity stress in citrus plants tissues (Zou and Wu, 2011; Kaushal et al., 2013 and Sharma et al. 2013). All seedlings grown under salinity stress condition and receiving SA application showed higher $\mathrm{K}^{+} / \mathrm{Na}^{+}$ratio in leaf tissues than those grown without SA application (Table 1). Such results are in harmony with those obtained by Daneshmand et al. (2009). They found that the application of SA increased $\mathrm{K}^{+} / \mathrm{Na}^{+}$ratio in plants grown under salt stress conditions. Also, Azooz et al. (2011) working on broad bean seedlings observed that salinity stress with $25 \%$ seawater increased $\mathrm{Na}$ and decreased $\mathrm{K}^{+}$content in shoot and root tissues of plants. Moreover, foliar spray with SA decreased $\mathrm{Na}$ concentration and increased $\mathrm{K}$ content in shoots and roots, these results lead to a consequently increase of $\mathrm{K}^{+} / \mathrm{Na}^{+}$ ratio in both organs of control and seawaterstressed plants. This indicated that SA could play an important role in selectivity of these ions under saline or non-saline conditions. They added that the positive effect of SA on $\mathrm{K}$ uptake and inhibitory effect on $\mathrm{Na}^{+}$could be responsible for managing of seawater stress on plants.

Generally, it can be concluded that using salicylic acid at $0.15 \mathrm{mM}$ (as a foliar spray) gave the highest values regarding the vegetative growth parameter, leaf peroxidase and catalase activities and the lowest value of leaf electrolyte leakage. In most cases, SA at $0.15 \mathrm{mM}$ (as a foliar spray) was the best in most results either with salinity or without it compared with SA at $0.25 \mathrm{mM}$ (as a soil application). This could be attributed to the quick response of the plant to the SA foliar application and avoid any environmental conditions which reduce the uptake of SA by roots application. The treatment with SA one month before salt application (acclimation) did not exhibit a pronounced effect in comparison with SA without acclimation.

1-Yield/vine:

Data in Table (1) clearly show that spraying elusters of Early sweet grapevines with $\mathrm{GA}_{3}$ at 10 to $40 \mathrm{ppm}$ or Sitofex at 2.5 to $10 \mathrm{ppm}$ was significantly effective in improving the yield relative to the check treatment. The promotion on the yield wa accompanied with increasing concentrations of each plant grow ha reghater. Using $\mathrm{GA}_{3}$ at 10 to 40 was significantly preferable than using Sitofex at 2.5 to $10 \mathrm{ppm}$ in improving the yield. A slight an unsignifieant promotion on the yield was attributed to increasing concentrations of $\mathrm{GA}_{3}$ from 20 to $4 p$ ppm and Sitofex from 5 to $10 \mathrm{ppm}$. The maximm yield was produced on the vines that received on spray of $\mathrm{GA}_{3}$ at $40 \mathrm{ppm}$ but the best treatment fron economical point of view was the application of $\mathrm{GA}_{3}$ at $20 \mathrm{ppm}$ (since no measurable promotion on the yield was recorded between 20 and $40 \mathrm{ppm}$ of $\mathrm{GA}_{3}$ ). Under such promised treatment, yield/ vine reached 13.6 and $14.0 \mathrm{~kg}$ during both season, respectively. The control vines produced 9.1 and 9.6 $\mathrm{kg}$ during 2013 and 2014 seasons, respectively. The percentage of increase on the yield due to application of $\mathrm{GA}_{3}$ at $20 \mathrm{ppm}$ over the check treatment reached 49.5 and $45.8 \%$ during both seasons, respectively. The beneficial effects of $G A$ on the yield might be attributed to their positive action on increasing cluster weight. The promotint effects of $\mathrm{GA}_{3}$ - on the yield was supported by the results of Dimovska et al., (2011) and Abu-Zahma and Salameh (2012) on different grapevine cvs.

The results regarding the beneficial effects of Sitofex on enhancing the yield are in harmony with those obtained by Juan et al. (2009); Abdel-Fattap et al., (2010) and Al-Obeed (2011).

\section{2-Harvesting date:}

It is clear from the data in Table (1) that all GA and Sitofex treatments had significantly delayed op the harvesting date of Early Sweet grapevines rather than the control treatment. The degree of delayness on harvesting date was correlated to the increase of the concentrations of both $\mathrm{GA}_{3}$ and Sitofex. Usint $\mathrm{GA}_{3}$ - significantly delayed harvesting date comparing with using Sitofex. Increasine encentrations of $\mathrm{GA}_{3}$ from 20 to 40 ppm and Sitofex form 5 to $10 \mathrm{ppm}$ failed to show significant delay on harvesting date. A considerable advancement on harvesting date was observed of untreated vines the great delay on harvesting date was observed on the vines that received $\mathrm{GA}_{3}$-at 4 ppm during both seasons. $\mathrm{GA}_{3}$ and Sitofex were shown by many atthors to retard the release of ethylene and the disappearance of pigments such as chlorophylls and carotenoids and onest of maturit start. Also they were responsible for prolonging pre maturity stages Nickell (1985). These results regarding the delaying effect of $\mathrm{GA}_{3}$ and Sitofex on harvesting date were in harmony with those obtained by Wassel et al., (2007), Kassem et at (2011), Abu-Zahra and Salameh (2012) and Refatt et al. (2012).

3-Cluster weight and dimensions:

It is evident from the data in Table (1) that treating clusters with $\mathrm{GA}_{3}$ at 10 to $40 \mathrm{ppm}$ or Sitofex at 2.5 to $10 \mathrm{ppm}$ was significantl accompanied with enhancing weight, length an width of eluster relative to the control treatment. 
The promotion was significantly associated with increasing concentrations of $\mathrm{GA}_{3}$ and Sitofex. Using

rM 
$\mathrm{GA}_{3}$-was significantly favourable than using Sitofex in this respect. The maximum values were recorded en the vines that received one spray of $\mathrm{GA}_{3}$-at 40 ppm. Meaningless promotion was detected with increasing concentrations of $\mathrm{GA}_{3}$ from 20 to $40 \mathrm{ppm}$ and Sitofex from 5 to $10 \mathrm{ppm}$. The untreat vines produced the minimum values during both seasons. The positive action of $\mathrm{GA}_{3}$ - on cluster weight and dimensions might be attributed to its essential role on stimulating cell division and enlargement of cells, the water absorption and the biosynthesis $\theta$ proteins which will lead to increase berry weight Dimovska et al., (2011); Abu-Zahra and Salameh, (2012) and Dimovskat al., (2014).

The previous essential role of $\mathrm{CPPU}$ on cluste weight was attributed to its higher content of eytokinin when applied to plants (Nickell, 1985).

\section{4- Shot berries \%:}

Data in Table (2) obviously reveal that percentage of shot berries in the clusters of Early Sweet grapevines was significantly controlled with spraying $\mathrm{GA}_{3}$ at 10 to $40 \mathrm{ppm}$ or Sitofex at 2.5 to 10 ppm relative to the check treatment. Using $\mathrm{GA}_{3}$ was preferable than using Sitofex in reducing the percentages of shot berries. There was a gradua reduction on the percentage of shot berries with increasing concentrations of $\mathrm{GA}_{3}$ and Sitofex. There was a slight reduction on such unfavourable phenomenon with increasing concentrations of $\mathrm{GA}_{3}$ form 20 to -40 ppm and Sitofex from 5 to 10 ppm. The minimmm values of shot berries (7.3 and 6.9 of during both seasons, respectively) were recorded on the clusters harvested from vines treated with GA at $40 \mathrm{ppm}$. The maximum values of shot berries $(12.0 \& 12.5 \%)$ during both seasons were recorded on the untreated vines during both seasons. The reducing effect of $\mathrm{GA}_{3}$ - on shot berries might be attributed to its important role on enhancing cel division and the biosynthesis of proteins Nickell (1985). These results were supported by the results of wassel et al. (2007) and Abu Zahra and Salamel (2012).

\section{5- Fruit quality:}

Data in Tables $(2,3 \& 4)$ clearly show that spraying elusters with-GA3 at 10 to 40 ppm-O Sitofex at 2.5 to $10 \mathrm{ppm}$ significantly was accompanied with enhancing weight, longitudina and equatorial of berry, total acidity \%, proteins of and percentages of $\mathrm{P}, \mathrm{K}$ and $\mathrm{Mr}$ and T.S.S. \% reducing sugars \%, T.S.S. / acid and tota earotenoids relative to the check treatment. The effect either increacer or decreacen with increasing concentrations of each auxin. Using $\mathrm{GA}_{3}$-significantly changed these parameters than using Sitofex. A slight effect was recorded on these quality parameters with increasing concentrations of $\mathrm{GA}_{3}$ from 20 to $40 \mathrm{ppm}$ and Sitofex from 5 to 10 ppm. From economical point of view, the best results with regard to fruit quality were observed due to treating clusters with $\mathrm{GA}_{3}$ at $20 \mathrm{ppm}$. Untreated vines produced enfavourable effects on frtit quality. These results were true during both seasons. The effect of $\mathrm{GA}_{3}$ - 0 in increasing berry weight and dimensions might be attributed to its effect in promoting celldivision and enlargement of cells, water uptake and the biosynthesis of proteins Nickell (1985). These results were in concordance with those obtained by Williams and Ayars (2005) and Dimovska al., (2014).

The higher content of Sitofex from cytokinins surly reflected on enhancing cell division and the elongation of berries Nickell (1985). These restlts were in agreement with these obtained by $\mathrm{Abt}$ Zahra (2013) and Retamales et al. (2015).

\section{CONCLUSIOA}

Treating Early Sweet grapevines once when the average berries reached $6 \mathrm{~mm}$ with $\mathrm{GA}_{3}$ at $20 \mathrm{ppm}$ was responsible for promoting yield and fruit quality.

\section{REFERENCES}

Aberg, B., 1981. Plant growth regulators. XII. Monosubstituted benzoic acid. Swedish J. Agric. Res., 11: 93-105.

Andersen, P. C., Brodbeck, B.V., 1988. Water relations and net $\mathrm{CO}_{2}$ assimilation of peach leaves of different ages. J. Amer. Soc. Hort. Sci., 113(2): 242-248.

Azooz, M. M.,Youssef, A.M., Ahmad, A., 2011 Evaluation of salicylic acid (SA) application on growth, osmotic solutes and antioxidant enzyme activates on broad bean seedlings grown under diluted seawater. Int. J. plant physiol. \& Biochemistry, 3(14): 253-264.

Bernstein, L., 1964. Osmotic adjustment of plants to saline media 11. Dynamic phase. Amer. J. Bot. 50:360-370.

Cameron, R.K., 2000. Salicylic acid and its role in plant defense responses: what do we really know? Physiol. Mol. Plant Pathol. 56: 91-93.

Cornelia, P., Cachita, D., Petrus, A., Pop, L., Chis, A., 2010. Involvement of salicylic acid on some biochemical parameters amelioration in salt stressed wheat (Triticum aestivum cv Crisana) plantlets. Analele Universității din Oradea, Fascicula:Protectia Mediului, XV 166-170.

Daneshmand, F., Arvin, M.J., Manouchehri, K. 2009. Effect of acetylsalicylic acid(Asperin) on salt and osmotic stress tolerance in Solanum bulbocastanum in vitro: enzymatic antioxidants. Am-Euras. J. Agric. \& Environ. Sci., 6(1): 9299.

Delaney, T.P., 2004. Salicylic Acid. In Plant Hormones: Biosynthesis, Signal Transduction, 
Action. P.J. Davies, ed (Dordrecht: Kluwer), pp. 681-699.

Dionisio-Sese, M. L., Tobita, S., 1998. Antioxidant responses of rice seedling to salinity stress. Plant Science, 135: 1-9.

Dubey, R. S., 2005. Photosynthesis in plants under stressful conditions. In Photosynthesi handbook. $2^{\text {nd }}$ Ed. M. Pessarakli C. R. C. Press, New York. P. 717-718.

El-Tayeb, M.A., 2005. Response of barley grains to the interactive effect of salinity and salicylic acid. Plant growth regulators. 45: 215-224.

Evenhuis, B., De-Waard, P. W., 1980. Principles and Practices in Plant Analysis. FAO Soil BULL., 38 (1): 152-163.

Garcia-Sanchez,F., Perez-Perez, J.G., Botia, P. Martinez, V., 2006. The response of young mandarin trees grown under saline conditions depends on the rootstock. Europ. J. Agronomy, 24: 129-139.

Garratt, L.C., Janagoudar, B.S., Lowe, K.C., Anthony,P., Power, J.P., Davey, M.R., 2002. Salinity tolerance and antioxidant status in cotton cultures. Free Radic. Biol.Med., 33: 502511.

Gunes, A., Inal, A., Alpaslan, M., 2005. Effects of exogenously applied salicylic acid on the induction of multiple stress tolerance and mineral nutrition in maize (Zea mays L.). Arch. Agron. Soil Sci., 51, 687-695.

Hayat, Q., Hayat, S., Irfan, M., Ahmad, A., 2010 Effect of exogenous salicylic acid under changing environment: A review. Environ. Expt. Bot., 68: 14-25.

Hela, B. A., Farouk, A., Arafet, M., Hajer, M., Ezz elddine, Z., 2009. Salicylic acid induced changes on some physiological parameters in tomato grown under salinity. The Proceedings of the International Plant Nutrition Colloquium XVI. Retrieved

Helaly, M. N. M., EL-Hosieny, A.R.H., 2011 Combined effects between genotypes and salinity on sweet orange during the developmental stages of its micropropagation. Research Journal of Botany., 6 (2): 38-57.

Hsiao, T. C., 1973. Plant responses to water sress. Ann. Rev. P1. Physiol., 24: 519-570.

Iglesias, D.J., Levy, Y., Cadenas, A.G., Tadeo, F.R., Primo-Millo, E., Talon, M., 2004. Nitrate improves growth in salt-stresses citrus seedlings through effects on photosynthetic activity and chloride accumulation. Tree physiology, 24 1027-1034.

Kar,M., Mishra, D., 1976. Catalase, peroxidase, and polyphenoloxidase activities during rice leaf senescence. Plant Physiol. 57: 315-319.

Karlidage, H., Yildirim, P., Turan, M., 2009. Salicylic acid ameliorates the adverse effect of salt stress on strawberry. Sci. Agric. (Piracicaba, Braz.), 66(2): 180- 187.

Kaushal, M., Kumar, L., Gill, M.I.S., Choudhary, O.P., Bali, S.K., 2013. Effect of salinity on survival and growth performance of in vitro grown rough lemon (Citrus jambhiri Lush.) seeds. Indian Journal of Biotechnology., 12: 284-286.

Khalil, H.A., Eissa, A.M., El-Shazly, S.M., AboulNasr, A.M., 2009. Physiological and anatomical responses of sour orange and Volkamer lemon to salinity stress and Mycorrhizal inoculation. Ph.D. Thesis, Fac. of Agric., Alexandria Univ., Egypt.

Khalil, H.A., Eissa, A.M., El-Shazly, S.M., AboulNasr, A.M., 2011. Improved growth of salinitystressed citrus after inoculation with mycorrhizal fungi. Scientia Horticulturae, 130: 624-632.

Khalil, H. A., 2013. Influence of vesiculararbuscular mycorrhizal fungi (Glomus spp.) on the response of grapevines rootstocks to salt stress. Asian J. Crop Sci., 5(4): 393-404.

Loake, G., Grant, M., 2007. Salicylic acid in plant defense-the players and protagonists. Current Opinion in Plant Biology, 10: 466-472.

Maas, E.V., 1993. Salinity and citriculture. Tree Physiol. 12:195-216.

Misra, N., Saxena, P., 2009. Effect of salicylic acid on proline metabolism in lentil grown under salinity stress. Plant Science 177: 181-189.

Mittler, R., 2002. Oxidataive stress, antioxidants and stress tolerance. Trends plant Sci.7: 405410.

Najafian, S., Khoshkhui, M., Tavallali, V., Saharkhiz, M.J., 2009. Effect of salicylic acid and salinity in Thyme (Thymus vulgaris L.): Investigation on changes in gas exchange, water relations, and membrane stabilization and biomass accumulation. Aust. J. of Basic and Appli. Sci., 3(3): 2620-2626.

Nir, G., Shulman, Y., Fanberstein, L., Lavee, S., 1986. Changes in the activity of Catalase (EC 1. 11. 1. 6) in relation to the dormancy of grapevine (Vitis vinifera L.) buds. Plant Physiology. 81: 1140-1142

Noreen, S., Ashraf, M., 2008. Alleviation of adverse effects of salt stress on sunflower (Helianthus annuus L.) by exogenous application of salicylic acid: growth and photosynthesis. Pak. J. Bot., 40(4): 1657- 1663.

Purcarea, C. , Cachita-Cosma, D., 2011. Salicylic acid involvement in salt stress alleviation in wheat (TriticumaestivumcvCrisana) seedlings. Studia Universitatis "VasileGoldiş", Seria Ştiințele Vieții. 21(3): 607- 614.

Prior, L. D., Grieve, A.M., Bevington, K.B., Slavich, P.G., 2007. Long-term effects of saline irrigation water on Valancia orange trees: 
relationships between growth and yield, and salt levels in soil and leaves. Aust. J. Agric. Res., 58: $349-358$.

Radwan, M. S., 1973. Leaf area estimation in berseem clover. Yugoslavian J. for Agric. (1) 53-56.

Sakhabutdinova, A. R., Fatkhutdinova, D.R., Bezrukova, M.V., shakirova, F.M., 2003 Salicylic acid prevents the damaging action of stress factors on winter wheat leaves Phytochemistry 67: 710-715.

Shaaban, M. M., Abd EL-Aal, A.M., Ahmed, F.F. 2011. Insight into the effect of salicylic acid on apple trees growing under sandy saline soil. Res. J. Agric \& Biol Sci., 7(2): 150-156.

Sharma, L. K., Kaushal, M., Bali, S.K., Choudhary, O.P., 2013. Evaluation of rough lemon (Citrus jambhiri Lush.) as rootstock for salinity tolerance at seedling stage under in vitro conditions. African Journal of Biotechnology. 12(44): 6267- 6275

Singh, G., 2009. Salinity-related desertification and management strategies. Land Degrad. and Develop., 20: 367-385.

Snedecor, G.W., Cochran, W.G., 1980. Statistica Methods. Seventh Edition. Iowa State. Univ. Press Ames, U. S. A. 507 pp.

Wu, Q., Zou, Y., Liu, W., Ye, X., Zai, H., Zhao, L., 2010. Alleviation of salt stress in citrus seedlings inoculated with mycorrhiza: changes in leaf antioxidant defense systems. Plant Soi Environ 56: 470-475.

Wei, Q., Liu, Y., Sheng, O., An, J., Zhou, G., Peng, S., 2013. Effect of salinity on the growth performance and macronutrient status of four citrus cultivars grafted on trifoliate orange.
African Journal of Biotechnology., 8(22): 26372644.

Yadava, U. L., 1986. A rapid and nondestructive method to determine chlorophyll in intact leaves. Hort. Sci. 21: 1449-1450.

Yehia, I. M. E., 2002. Physiological studies on salinity tolerance of persimmon seedlings. M. Sc. Thesi, Fac. Agric. Moshtohor., Zagazig University.

Yildirim, E., Turan, M., Guvenc, I., 2008. Effect of foliar salicylic acid applications on growth, chlorophyll, and mineral content of cucumber grown under salt stress. J. Plant Nutrition, 31: 593-612.

Yusuf, M., Hasan, S.A., Ali, B., Hayat, S., Fariduddin, Q., Ahmed, A., 2008. Effect of salicylic acid on salinity induced changes in Brassica juncea. J. Integrative Plant Biol., 50(8): 1196-1102.

Zhang Y., Chen, K.S., Zhang, S.L., Ferguson, I., 2003. The role of salicylic acid in postharvest ripening of kiwifruit. Postharvest Biol. Technol., 28: 67-74

Zou, Y.N., Wu, Q.S., 2011. Sodium chloride stress induced changes in leaf osmotic adjustment of trifoliate orange (Poncirus trifoliata) seedlings inoculated with mycorrhizal fungi. Not. Bot. Hort. Agrobo., 39(2): 64-69.

Zou, Y.N., Liang, Y.C., Wu, Q.S., 2013 Mycorrhizal and non-mycorrhizal responses to salt stress in trifoliate orange: plant growth, root architecture and soluble sugar accumulation. Int. J. Agric. Biol., 15: 565- 569. 


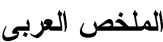

تأثير حمض الساليسيليك على النمو والحالة الفسيولوجية و المعدنية لنباتات النارنج النامية تحت ظروف الاجهاد الملحى

سامي محمود الثاذلي، هلي علي عبد المحسن خليل، شيماء فخري

قسم الفاكهة - كلية الزر اعة- جامعة الاسكندرية

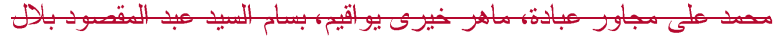

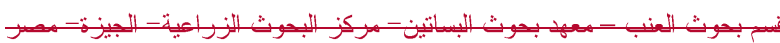

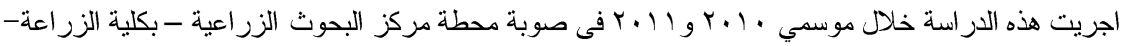

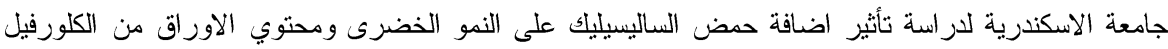

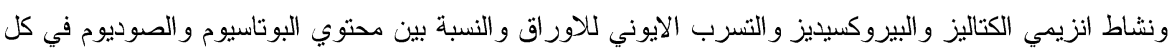

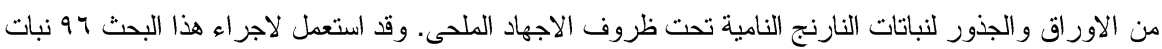

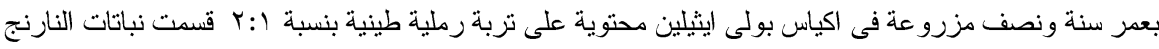

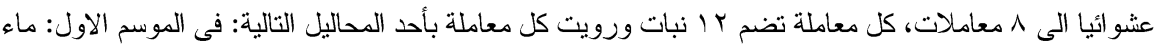

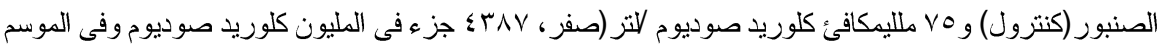

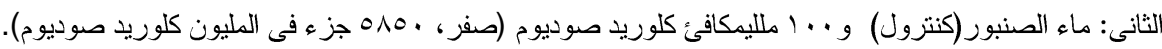


رويت كل النباتات مرتين اسبوعيا بمعدل . .0 ملليلينز بمحلول الرى الملحى. تم اخذ ؛ معاملات من المعاملات الكلية وعوملت بحمض الساليسيليك بتركيز 10 , · ملليمكافئ حمض الساليسيليك) (كمعاملة رش على الاوراق )وبتركيز ه ب, ، ملليمكافئ حمض الساليسيليك (كمعاملة اضافة فى التربة مع محلول الرى) مع وجود او بدون وجود الملوحة فى كلا الموسمين. ونث اخذ معاملتين من المعاملات الكلية ونم معاملاتهم بحمض الساليسيليك بتزكيز 10 , • و هr, • ملليمكافئ حمض الساليسيليك كمعاملة مبئية قبل اضافة معاملة الملوحة بشهر (معاملة الاقلمة)، ومعاملة المقارنة وكانت تعامل بماء الصنبور فقط و استخدم تصميم القطاعات العشوائية الكاملة فى تتفيذ التجربة مع باته مكررة لكل من الثمانى معاملات المستخدمة فى هذا البحث (^ معاملات X Y I مكررة) وبذلك استخدم جو نبات من نباتات النارنج المختبرة لمدة 11 (1 يوم و ^1 ايوم فى الموسم الاول والثانى على التو الى. اوضحت النتائج ان الاجهاد الملحي كان له ناثير سلبي علي نمو النبات ومحتوي الاوراق من الكلورفيل بالرغم من ذلك النباتات المعاملة الساليسيليك اعطت اعلي طول للنبات ومساحة للاوراق وكانت الاعلي في الوزن الجاف الكلي وكذلك اعلي محتوي لكي لكلورفيل الاوراق وذلك تحت ظروف الاجهاد الملحي. انخفض نشاط انزيم البيروكسيديز في الاوراق بينما ارتفع التسرب الايوني نتيجة للاجهاد الملحي. ادت المعاملة الساليسيليك الي ارتفاع نشاط انزيمي البيروكسيديز و الكتاليز و انخفاض التسرب الايوني بالمقارنة بالكنترول تحت ظروف الاجهاد الملحي. ادت معاملة الساليسيليك الرش الورقي بتزكيزه 1, •الي زيادة نسبة البوتاسيوم الي الصوديوم في كل من الاوراق والجذور وذلك بالمقارنة بمعاملة الكنتزول. عامة وجد ان اعلي قيم للقياسات تم الحصول عليها لمعاملة الرش الورقي الساليسيليك بتركيز 1 ا.ر • ملي مولر · وقد وجد ان المعاملة الساليسيليك لمدة شهر قبل معاملة الملوحة(معاملة الاقلمة) لم يكن لها تاثثر علي النباتات بالمقارنة بمعاملة الساليسيليك بدون اقلمة. 